\title{
PROGRAM PELATIHAN KEWIRAUSAHAAN DASAR DAN PEMBUATAN MODUL KEWIRAUSAHAAN UNTUK SMK ATURMUDIAH
}

\author{
Mutia Tri Satya \\ mutia.satya@gmail.com \\ Ayi Tejaningrum \\ ayitejaningrum@yahoo.com \\ Hanifah \\ hanifahoney@gmail.com
}

\section{SEKOLAH TINGGI ILMU EKONOMI EKUITAS}

\begin{abstract}
ABSTRAK
SMK Aturmudiah terletak di Kabupaten Garut, serta merupakan SMK PJJ atau SMK Pembelajaran Jarak Jauh yang memiliki 75 siswa. SMK ini adalah sekolah bentuk paket C, yaitu bagi siswa yang ingin mendapatkan ijazah sekolah tingkat atas atau Sekolah Menengah atas namun memiliki hambatan untuk melanjutkan pendidikannya maka harus mengikuti ujian Paket $C$. Mengingat kondisi ekonomi masyarakat yang tertinggal dan sulitnya akses menuju fasilitas pendidikan (sekolah), membuat banyak dari masyarakat setempat putus sekolah dan tidak melanjutkan pendidikannya. Hal-hal tersebut yang menghambat pembangunan dan pengembangan pendidikan di SMK Aturmudiah yang menjadi solusi bagi mereka yang memiliki keterbatasan pendidikan di Desa Cintanegara. Selain menyediakan sarana untuk belajar, melalui program ini kami juga ingin memberikan pengetahuan mengenai pentingnya kewirausahaan dengan tujuan untuk memberikan pengetahuan mengenai kewirausahaan dan menciptakan kemandirian ekonomi bagi para siswa melalui pelatihan dan modul pembelajaran kewirausahaan.
\end{abstract}

Kata kunci: Ekonomi, Kewirausahaan, dan Pendidikan.

\section{PENDAHULUAN}

Pada saat akhir millenium kedua seperti sekarang, Indonesia adalah negara yang relatif mudah mengalami perubahan fundamental. Kompleksitas pendidikan dan tuntutan masyarakat mewujudkan sebuah tatanan baru untuk pendidikan yang lebih baik. Perkembangan pendidikan yang semakin dinamis menyebabkan pola dan bentuk penyampaian secara konvensioanal yang telah berpuluh tahun berjalan tidak mampu lagi bertahan.

Pendidikan Nasional dilaksanakan dengan tujuan untuk membentuk kualitas Sumber Daya Manusia (SDM) yang seutuhnya, yaitu manusia yang beriman dan bertakwa terhadap Tuhan yang Maha Esa, berbudi pekerti luhur, berkepribadian, berdisiplin, beretos kerja tinggi, tangguh, bertanggung jawab, mandiri, cerdas, terampil dan sehat jasmani dan rohani. 
Peningkatan mutu pendidikan, pemerataan pendidikan, efesiensi, dan efektifitas hasil pendidikan akan berhasil apabila dilaksanakan dengan terencana, terarah, terukur, dan berkesinambungan serta ditunjang dengan pengorganisasian yang tepat dan sarana prasarana yang memadai.

Hingga saat ini, pelaksanaan sistem pendidikan di Indonesia masih belum merata. Sedangkan di era digital ini, mereka yang memiliki latar pendidikan yang kurang akan sulit bertahan dalam mengikuti perkembangan dan pergerakan masyarakat, salah satunya dari segi mencari pekerjaan. Oleh karena itu, penting untuk membangun jiwa kewirausahaan sebagai alternatif dalam proses perbaikan ekonomi masyarakat. Terdapat dua faktor untuk pembentukan jiwa kewirausahaan, yakni faktor internal dan eksternal. Faktor internal berasal dari dalam diri seorang wirausahawan, diantaranya berupa sifat-sifat personal, sikap, kemauan dan kemampuan individu yang dapat memberi kekuatan individu untuk berwirausaha. Sedangkan faktor eksternal berasal dari luar diri pelaku entrepreneur yang dapat berupa unsur dari lingkungan sekitar seperti lingkungan keluarga, lingkungan dunia usaha, lingkungan fisik, lingkungan sosial ekonomi dan lain-lain (Suharti \& Sirine, 2011).

Yang menjadi sasaran dalam pengabdian ini adalah pengembangan pendidikan dalam bidang kewirausahaan yang akan dilaksanakan di SMK Aturmudiah, Kabupaten Garut. Secara sosial, kondisi masyarakat disekitar wilayah SMK Aturmudiah masih memiliki rasa kebersamaan dan tingkat gotong royong yang tinggi, namun secara ekonomi mereka masih tertinggal dengan wilayah yang lain. Keterbatasan ekonomi juga terlihat dari kondisi infrastruktur yang masih terbatas dan sulit untuk dijangkau oleh pihak luar. Hal-hal tersebut menyebabkan terhambatnya pembangunan dan pengembangan pendidikan di SMK Aturmudiah.
Melalui program ini, kami harap dapat memberikan pengetahuan mengenai pentingnya kewirausahaan yang bertujuan untuk memberikan pengetahuan mengenai kewirausahaan. Berdasarkan tujuan di atas, ada 3 (tiga) yang di harapkan sebagai berikut:

1. Memberikan ilmu mengenai kewirausahaan, agar menjadikan siswa mampu dalam mencipatakan kemandirian dalam perekonomian. Dengan terbentuknya kemandirian ekonomi pada para siswa SMK Aturmudiah diharapkan juga mampu membawa perubahan yang cukup baik kepada wilayah sekitar SMK Aturmudiah

2. Melengkapi sarana dan prasarana yang dibutuhkan siswanya untuk mampu meningkatkan pelayanan belajar kepada siswa. Hal tersebut membuat modul kewirausahaan sebagai pegangan atau buku panduan yang akan memotivasi siswa untuk berwirausaha, dengan demikian program ini dapat menjadi program jangka panjang yang manfaatnya dapat dirasakan secara berkelanjutan.

3. Melengkapi media pembelajaran bagi guru dalam pelaksanaan PBM. Hal tersebut dilakukan dengan pengadaan White Board sebagai sarana pendukung proses belajar mengajar.

Banyak faktor yang menentukan upaya untuk mencapai tujuan pendidikan, antara lain sarana dan prasarana, kondisi sosial ekonomi orang tua siswa, potensi guru dan metode yang di gunakan dalam proses pendidikan. Selain itu, kerja sama dengan pemerintah untuk terus menerus secara berkelanjutan membenahi seluruh faktor yang mempengaruhi upaya peningkatan kualitas pendidikan tersebut.

Menurut (Lastariwati, 2012) pembelajaran kewirausahaan penting dilakukan sebagai upaya untuk mencapai kualitas lulusan kejuruan yang bertanggung jawab, kreatif, inovatif, sportif, dan 
berkewirausahaan. Jiwa dan watak yang terdapat dalam kewirausahaan tersebut dipengaruhi oleh beberapa hal, yaitu; keterampilan, kemampuan, atau kompetensi (Darwin, et al., 2018). Dalam penelitiannya juga dikatakan bahwa seorang wirausaha adalah seseorang yang memiliki kemampuan untuk menciptakan sesuatu yang baru dan berbeda (ability to create the new and different). Menurut Purhantara (2013), kemampuan kreatif dan inovatif dalam berwirausaha secara nyata tercermin dalam 4 hal, yaitu (1) start up atau kemampuan dan kemamuan untuk memulai usaha; (2) creative atau kemampuan untuk mengerjakan sesuatu yang baru; opportunity, kemauan dan kemampuan untuk mencari peluang; (3) risk bearing atau kemampuan dan keberanian untuk menanggung risiko; dan kemampuan untuk mengembangkan ide dan meramu sumber daya.

Wibowo (2011) mengatakan bahwa menghasilkan lulusan sekolah kejuruan yang siap kerja dan siap berwirausaha merupakan tantangan bagi sekolah kejuruan, Hal tersebut tidak lepas dari rendahnya tingkat pasar tenaga kerja jika dibandingkan dengan angkatan kerja. Dengan demikian, kewirausahaan diyakini menjadi salah satu solusi untuk mengatasi ketidakseimbangan suply \& demand dalam bidang ketenagakerjaan di Indonesia. Namun, dengan model pembelajaran yang sama akan menghasilkan lulusan SMK yang terbaik dan memiliki minat untuk berwirausaha.

\section{Identifikasi Masalah}

Secara institusional pendidikan yang diselengarakan di SMK Aturmudiah yang beralamat di Cibodas RT.02 RW.13 Desa Cintanegara Kabupaten Garut, masih memiliki banyak kendala dalam pelaksanaan pendidikan. SMK ini merupakan SMK PJJ atau SMK Pembelajaran Jarak Jauh yang memiliki 75 siswa. SMK ini merupakan sekolah paket C, yaitu bagi siswa yang ingin mendapatkan ijazah sekolah tingkat atas atau Sekolah Menengah atas namun memiliki hambatan untuk melanjutkan pendidikannya maka harus mengikuti ujian Paket $\mathrm{C}$.

SMK Aturmudiah ini tidak memiliki bangunan yang tetap, dalam proses belajar mengajarnya siswa yang terdiri dari 75 siswa dan guru ini menggunakan masjid sebagai tempat proses belajar. Sekolahnya diadakan setiap hari sabtu dan minggu saja. Semua siswanya memiliki latar belakang ekonomi yang kurang mampu, SMK ini bertujuan untuk memberikan bekal yang cukup kepada peserta didik dan dapat melakukan pendidikan ke jenjang yang lebih tinggi dalam dimensi yang lebih luas.

Berdasarkan hal-hal tersebut selain dengan pengadaan bantuan kan sarana dan prasarana pendidikan, maka dapat disimpulkan bahwa pembelajaran kewirausahaan sangat penting untuk meningkatkan, pengetahuan, ketrampilan, dan kompetensi siswa dalam berwirausaha. Hal tersebut juga bertujuan untuk menyiapkan mental siswa untuk menyiapkan diri sebagai entrepreneur pada kondisi lapangan pekerjaan yang mulai menurun. Melalui pelatihan ini, diharapkan dapat menjadi bekal ilmu pengetahuan dan meningkatkan motivasi bagi para siswa di SMK Aturmudiah untuk berwirausaha.

\section{METODOLOGI PELAKSANAAN}

Metode yang digunakan dalam pengabdian ini adalah dengan cara Pendidikan Masyarakat, yaitu penyuluhan yang bertujuan meningkatkan pemahaman serta kesadaran. Pelatihan yang dilakukan diberikan langsung kepada para peserta yang merupakan siswa SMK Aturmudiah. Selama pelaksanaan pelatihan peserta juga didampingin oleh para guru atau tenaga pendidik dan pengurus dari SMK Aturmudiah. Selain itu, pembuatan modul juga dilakukan untuk diberikan kepada tenaga pendidik sebagai pedoman dalam memberikan pembelajaran kewirausahaan bagi para peserta didik di SMK Aturmudiah. Secara berurutan pelaksanaan pelatihan di SMK Aturmudiah melalui berbagai tahapan sebagai berikut: 
1. Tahapan awal

- Mengidentifikasi lingkungan SMK Aturmudiah.

- Pemilihan serta membuat pengelompokan target pelatihan : siswa SMK Aturmudiah

2. Tahapan Lanjutan

- Melaksanakan Pelatihan Kewirausahaan Dasar bagi siswa SMK Aturmudiah. Pelatihan dilaksanakan pada tanggal 17 September 2020.

- Menyediakan sarana yang diperlukan, seperti; buku tulis, modul kewirausahaan, dan alat pengeras suara untuk mendukung proses pembelajaran dan menstimulasi siswa agar membentuk minat serta motivasi siswa dalam berwirausaha

\section{Tahapan Akhir}

- Melaksanakan pendampingan (monitoring dan evaluasi hasil dari pelaksanaan kegiatan)

\section{HASIL DAN LUARAN}

\section{Identifikasi lingkungan SMK Aturmudiah}

SMK Aturmudiah merupakan sebuah sekolah dengan program kesetaraan bagi para warga yang mengalami putus sekolah agar dapat melanjutkan pendidikannya. Saat ini, para siswa tidak memiliki gedung atau bangunan sekolah yang selayaknya digunakan sebagai sarana untuk melakukan kegiatan pendidikan. Para siswa belajar di sebuah selasar masjid, yang tentunya membutuhkan tempat belajar yang lebih layak daripada itu untuk melakukan pembelajaran, agar dapat melakukan kegiatan belajar dengan lebih baik lagi.

\section{Target Pelatihan}

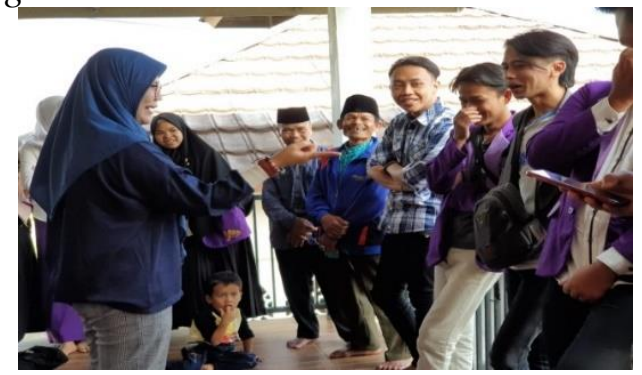

Gambar 1 Pelaksanaan Pelatihan

Kewirausahaan di SMK Aturmudiah

Target pelatihan adalah para siswa dan siswi dari SMK Aturmudiah, dengan tujuan penelitian adalah untuk memupuk dan menumbuhkan jiwa kewirausahaan dalam diri para siswa siswi tersebut. Memberikan gambaran mengenai bagaimana caranya untuk memulai usaha dan menumbuhkan kepercayaan diri untuk berwirausaha tanpa melihat usia ataupun latar belakang pendidikan. Hal-hal tersebut bertujuan agar para siswa mampu memperbaiki taraf hidup melalui wirausaha. Jumlah peserta pelatihan yang hadir adalah sebanyak 27 orang yang merupakan siswa dan siswi dari SMK Aturmudiah. Dari seluruh peserta pelatihan terdapat beberapa siswa yang memiliki minat dalam berwirausaha, bahkan satu diantaranya sudah memulai usaha di bidang konveksi yaitu menjahit. Sebagian dari para peserta mengatakan ingin memulai berwirausaha untuk memperbaiki taraf hidup mereka dan keluarganya.

Pemberian sarana penunjang pembelajaran

Pemberian sarana penunjang pembelajaran berupa alat tulis yang dibagikan langsung kepada para peserta pelatihan, penyerahan sertifikat dan alat pengeras suara kepada pengelola SMK Aturmudiah, penyerahan modul ajar kewirausahaan kepada tenaga pendidik SMK Aturmudiah. Pemberian sarana-sarana tersebut dilakukan setelah seluruh agenda penelitian selesai, untuk menunjang kegiatan belajar siswa siswi SMK Aturmudiah tentang kewirausahaan di waktu yang akan datang . 


\section{Hasil Akhir}

Hasil akhir dari pengabdian ini adalah dilakukannya monitoring terhadap peserta pelatihan dari SMK Aturmudiah dalam berwirausaha untuk melihat apakah telah tumbuh minat berwirausaha dan melakukan pendampingan apabila diperlukan. Serta mengembangkan siswa siswi yang telah memiliki minat dalam berwirausaha serta membantu mengembangkan siswa yang telah melakukan wirausaha agar terus termotivasi dan ingin meningkatkan untuk melakukan kegiatan berwirausaha tersebut agar menjadi seorang wirausaha yang sukses dan akan membuat rekan-rekan dari siswasiswi tersbut termotivasi untuk melakukan hal yang sama.

\section{KESIMPULAN DAN SARAN}

Hasil dari kegiatan ini adalah Masyarakat teredukasi melalui pendidikan dan pelatihan nonformal sehingga mampu mempromosikan produk UKM yang dihasilkan secara digital, Membantu meningkatkan kemampuan kreativitas dan keterampilan masyarakat untuk digunakan dalam mempromosikan usaha-usaha baru. Produk lokal hasil UMKM kelurahan Ciwaduk dapat dikenal masyarakat luas dan menjadi produk unggulan yang bernilai ekonomi. Memberikan peluang usaha bagi masyarakat yang ingin memulai usaha makanan, dan Meningkatkan taraf hidup masyarakat.

Kegiatan ini di dukung oleh Kelurahan Ciwaduk sebagai bentuk dukungan dari pemerintah terhadap kelompok Usaha Kecil Menengah. Hal ini terlihat dengan diadakannya kegiatan ini yang berlokasi di Kelurahan Ciwaduk.

Saran dari kegiatan ini adalah perlu adanya binaan yang berkelanjutan, seminarseminar dan workshop yang mendukung kegiatan para pelaku UMKM tentunya dengan adanya dukungan dari kelurahan setempat.

\section{DAFTAR PUSTAKA}

Darwin, R., Widiarsih, D., Murialti, N., Hidayat, M., Hadi, M. F., \& Asnawi, M. (2018). Menumbuhkan Jiwa Wirausaha Siswa dan Guru Sekolah Menengah Kejuruan (SMK) PGRI Pekanbaru Melalui Pelatihan Pembuatan Sabun Cuci Piring Cair. Jurnal Pengabdian Untuk Mu NegeRI, Vol.2, No.1, 10-16.

Lastariwati, B. (2012). Pentingnya Kelas Kewirausahaan Pada SMK Pariwisata. Jurnal Pendidikan Vokaso, Vol. 2, No. 1, 71-80.

Purhantara, W. (2013). Analisis Kepemilikan JIwa Kewirausahaan: Evaluasi Outcome Pendidikan Menengah di Jawa. Jurnal Economia, Vol. 9, No. 2.

Suharti, L., \& Sirine, H. (2011). FaktorFaktor yang Berpengaruh Terhadap Niat Kewirausahaan. Jurnal Manajemen dan Kewirausahaan, VOL.13, NO. 2, 124-134.

Wibowo, M. (2011). Pembelajaran Kewirausahaan dan Minat Wirausaha Lulusan SMK. Eksplanasi, Vol. 6, No. 2, 109-122. 